\title{
New distribution records of the intertidal pseudoscorpion Parahya submersa (Pseudoscorpiones: Parahyidae)
}

\author{
Mark S. Harvey ${ }^{1}$, Julianne Waldock ${ }^{1}$, Roy J. Teale ${ }^{2}$ and Jenni Webber ${ }^{3}$ \\ Department of Terrestrial Invertebrates, Western Australian Museum, Locked Bag 49, \\ Welshpool DC, Western Australia 6986, Australia \\ ${ }^{2}$ Biota Environmental Sciences Pty Ltd, PO Box 155, Leederville, Western Australia 6903, Australia \\ P.O. Box 2280, Humpty Doo, Northern Territory 0836, Australia
}

\begin{abstract}
The intertidal pseudoscorpion Parahya submersa (Bristowe) is recorded from northern Australia for the first time, and new specimens are recorded from Singapore and New Caledonia.
\end{abstract}

\section{INTRODUCTION}

Intertidal pseudoscorpions are found in many parts of the world and some genera are totally or mostly restricted to seashore habitats. Prominent genera occurring in intertidal habitats are Garypus L. Koch (Garypidae) (e.g. Lee, 1979), Halobisium Chamberlin (Neobisiidae) (e.g. Schulte, 1976) and Paraliochthonius Beier (Chthoniidae) (e.g. Vachon, 1960; Muchmore, 1967, 1972; Muchmore, 1984; Mahnert, 1986). Other less widespread genera such as Nannochelifer Beier (Cheliferidae) and Parahya Beier (Parahyidae) also appear to be restricted to the intertidal zone. The mechanisms by which these small arachnids are able to survive in such inhospitable habitats are not fully known but their ability to spin a silken chamber (Gabbutt, 1962, 1966; Weygoldt, 1969) may enable them to survive prolonged periods of inundation.

The genus Parahya is currently known from a single species, $P$. submersa (Bristowe), recorded from several locations within the Australasian region ranging from Singapore through to the Micronesian islands and New Caledonia. Harvey (1991b) redescribed $P$. submersa, originally named Obisium submersum by Bristowe (1931) from Singapore, and treated Parahya pacifica Beier (1957) from the Caroline Islands as a junior synonym. The genus was later transferred to a separate family, the Parahyidae, by Harvey (1992). Recent collecting of pseudoscorpions from littoral habitats in northern Australia has revealed several specimens of $P$. submersa representing the first records of this species from the Australian continent. We also document new records of $P$. submersa from Singapore and New Caledonia, and present a distribution map showing known occurrences of the species.

The specimens recorded below are lodged in the Museum and Art Gallery of the Northern Territory, Darwin (MAGNT) and the Western Australian Museum, Perth (WAM).

\section{Family Parahyidae Harvey \\ Genus Parahya Beier \\ Parahya submersa (Bristowe) \\ Figures 1, 2}

Obisium submersum Bristowe, 1931: 465, figs 3-6; Roth and Brown, 1976: 128.

Parahya pacifica Beier, 1957: 15-16, figs 4b, 5 (synonymised by Harvey, 1991b: 288).

Parahya submersa (Bristowe): Harvey, 1991a: 315; Harvey, 1991b: 288-290, figs 1-12; Harvey, 1992: figs 117-125; Judson, 1997: 42.

Microcreagris sp.: Bigot, 1992: 113.

\section{Material examined}

Australia: Northern Territory: 1 , Plater Beach, west side of Darwin Harbour, $12^{\circ} 29.25^{\prime} \mathrm{S}$, $130^{\circ} 46.55^{\prime}$ E, 21 April 1999, J.K. Webber (MAGNT A951); Western Australia: 1 \&, Bonaparte Archipelago, Steep Head Island, $14^{\circ} 26^{\prime} 52^{\prime \prime} \mathrm{S}, 125^{\circ} 59^{\prime} 44^{\prime \prime} \mathrm{E}$, intertidal zone, 6 September 2002, M.S. Harvey, R.J. Teale (WAM T57298). New Caledonia: 3 t, 4 \%, 3 deutonymphs, $5 \mathrm{~km}$ SE. of Mou, 21 $06^{\prime} 30^{\prime \prime} \mathrm{S}$, $165^{\circ} 27^{\prime} 30^{\prime \prime} \mathrm{E}$, littoral zone, 11 February 1993, M.S. Harvey, N.I. Platnick, R.J. Raven (WAM T62568). Singapore: 1 t , Labrador Beach, $1^{\circ} 16^{\prime} \mathrm{N}, 103^{\circ} 48^{\prime} \mathrm{E}$, under rock in littoral zone, 24 October 1992, J.M. Waldock (WAM T62566); 5 ¿, 8 \%, 1 deutonymph, Labrador Beach, $1^{\circ} 16^{\prime} \mathrm{N}, 103^{\circ} 48^{\prime} \mathrm{E}$, under rocks, tidal zone, 8 March 1994, J.M. Waldock (WAM T62567).

\section{Remarks}

Parahya submersa has been recorded throughout the Australasian region including Singapore, Sulawesi, the Caroline Islands and New Caledonia (Bristowe, 1931; Beier, 1957; Harvey, 1991b). The new specimens listed above include material from some of these regions including the type locality of 


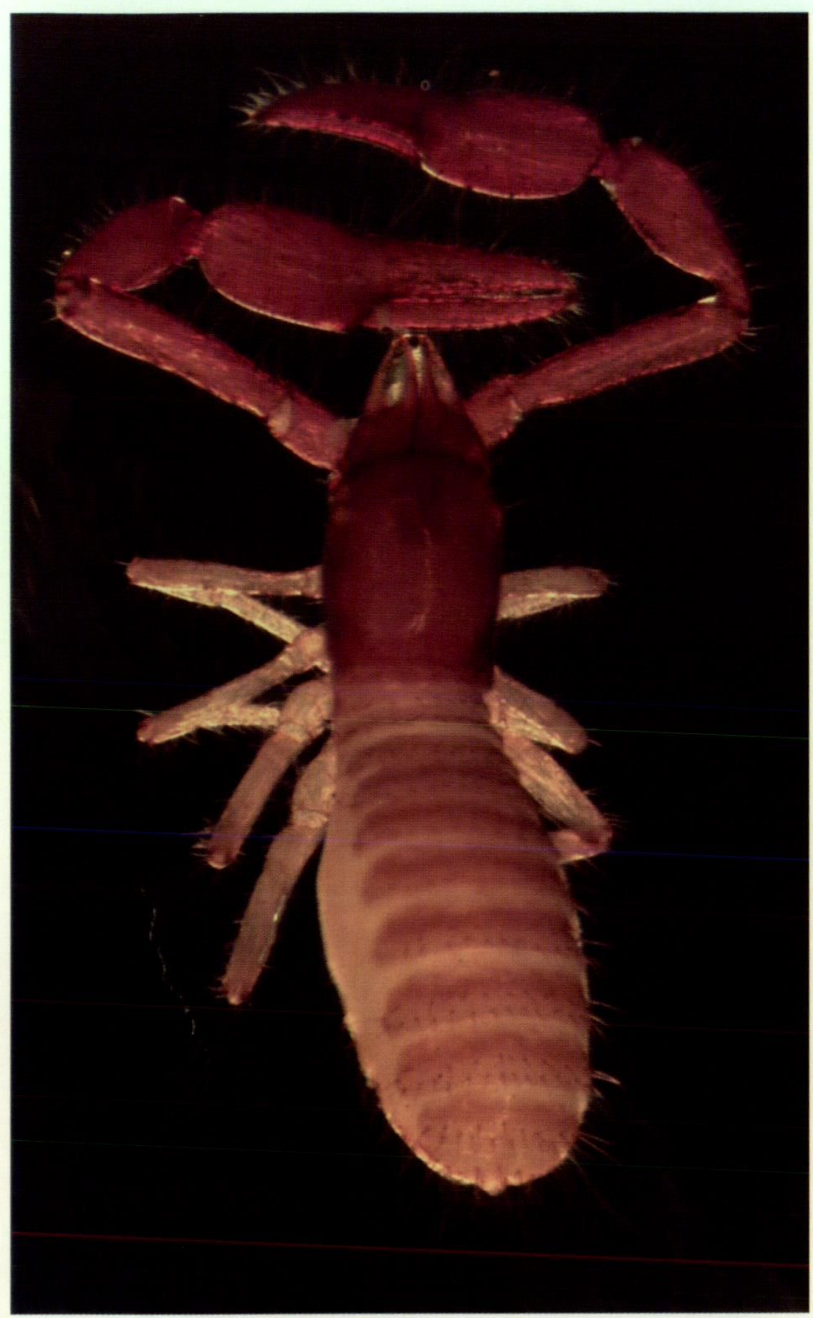

Obisium submersum, Singapore, and New Caledonia. The Australian records represent a slight range extension, indicating that $P$. submersa has a wider distribution in the Australasian region than previously recognised. The record of Microcreagris sp. from Récif Croissant, New Caledonia by Bigot (1992) appears to be based upon the same specimens identified by Harvey (1991b) as $P$. submersa.

All specimens of $P$. submersa reported to date (Bristowe, 1931; Beier, 1957; Harvey, 1991b) are from littoral habitats suggesting that it is an obligate littoral species. The following habitats have been noted on locality labels accompanying specimens: "beach, sea" and "beneath boulders on seaward reef" (Caroline Islands); "dans la zone supérieure de l'estran (zone à gros chiton)" and "levée détritique de madrépores" (New Caledonia); "under rocks on sand, half way down littoral zone" (Singapore); and "below log on mud at around midtide level in mangrove" (Sulawesi). The new records are from similar habitats. The specimens from Steep Head Island, Western Australia, were found on the underside of rocks that were exposed on the beach at low tide, but which were fully covered at high tide. They occurred amongst polychaete tubes and other intertidal marine invertebrates, but no trace of a silken chamber was observed. The specimens ran backwards quickly when disturbed.

Figure 1 Parahya submersa (Bristowe), female from Steep Head Island, Western Australia (WAM T62566).

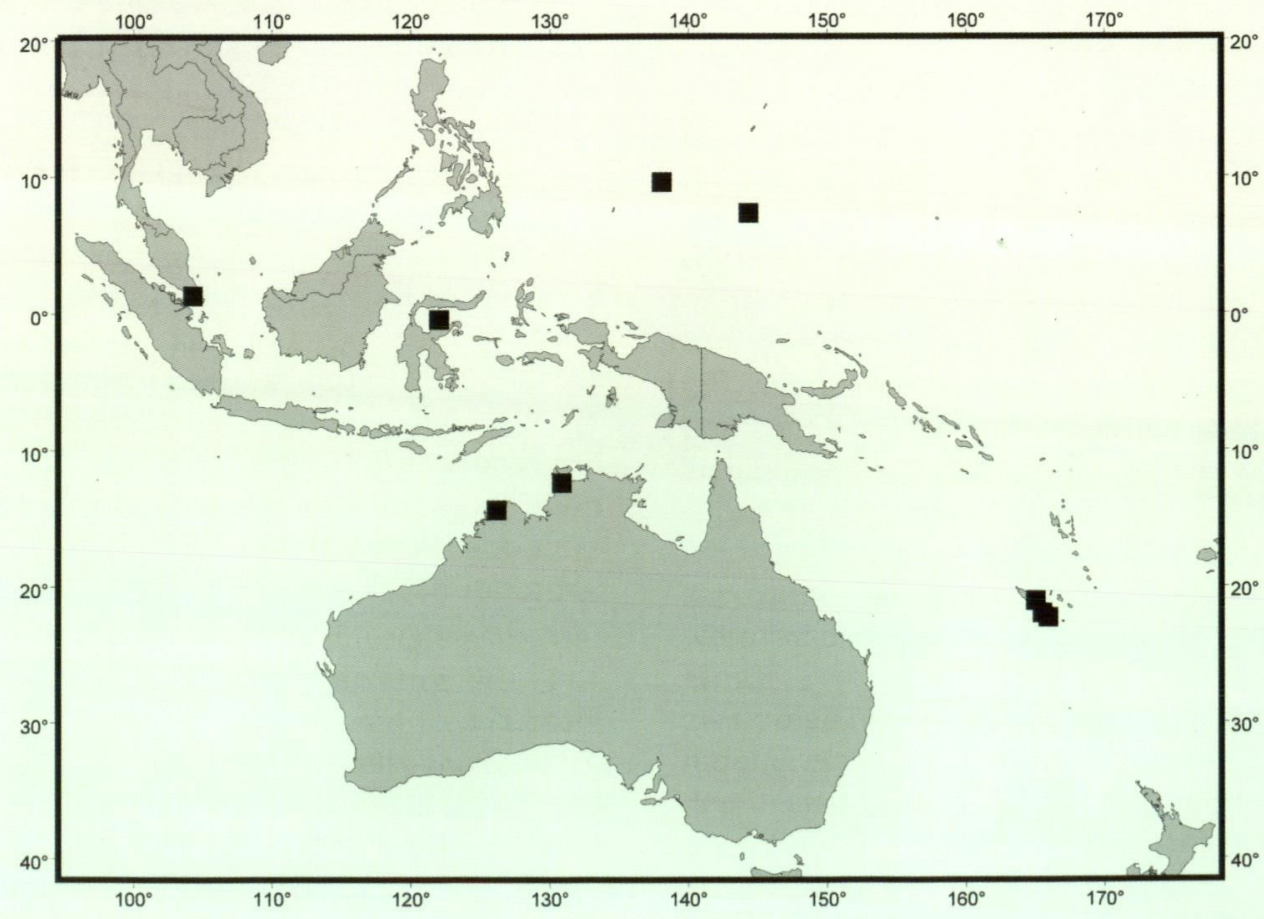

Figure 2 Map of Australasia showing known distribution of Parahya submersa (Bristowe). 


\section{ACKNOWLEDGEMENTS}

MSH wishes to thank Norman Platnick and Robert Raven for facilitating the trip to New Caledonia, Gavin Dally for the loan of material from the MAGNT, and Ric How who facilitated the trip to the Kimberley region of Western Australia. We are grateful to two anonymous referees for their comments on a draft of the manuscript.

\section{REFERENCES}

Beier, M. (1957). Pseudoscorpionida. Insects of Micronesia 3: $1-64$.

Bigot, L. (1992). Contribution à l'étude des peuplements littoraux et côtiers de la Nouvelle-Calédonie (Grande Terre, lle des Pins) et d'une île Loyauté (Ouvéa): deuxième inventaire des Arthropodes. Annales de la Société Entomologique de France, nouvelle series 28: 113-123.

Bristowe, W.S. (1931). Notes on the biology of spiders. IV. Further notes on aquatic spiders, with a description of a new species of pseudoscorpion from Singapore. Annals and Magazine of Natural History (10) 8: 457-465.

Gabbutt, P.D. (1962). 'Nests' of the marine false-scorpion. Nature 196: 87-88.

Gabbutt, P.D. (1966). An investigation of the silken chambers of the marine pseudoscorpion Neobisium maritimum. Journal of Zoology, London 149: 337-343.

Harvey, M.S. (1991a). Catalogue of the Pseudoscorpionida. Manchester University Press: Manchester.

Harvey, M.S. (1991b). Notes on the genera Parahya Beier and Stenohya Beier (Pseudoscorpionida: Neobisiidae). Bulletin of the British Arachnological Society 8: 288292.

Harvey, M.S. (1992). The phylogeny and classification of the Pseudoscorpionida (Chelicerata: Arachnida). Invertebrate Taxonomy 6: 1373-1435.
Judson, M.L.I. (1997). Catalogue of the pseudoscorpion types (Arachnida: Chelonethi) in the Natural History Museum, London. Occasional Papers on Systematic Entomology 11: 1-54.

Lee, V.F. (1979). The maritime pseudoscorpions of Baja California, México (Arachnida: Pseudoscorpionida). Occasional Papers of the California Academy of Sciences 131: i-iv, 1-38.

Mahnert, V. (1986). Die Pseudoskorpione (Arachnida) Kenyas. VIII. Chthoniidae. Revue Suisse de Zoologie 92: $823-843$.

Muchmore, W.B. (1967). Two new species of the pseudoscorpion genus Paraliochthonius. Entomological News 78: 155-162.

Muchmore, W.B. (1972). The pseudoscorpion genus Paraliochthonius (Arachnida, Pseudoscorpionida, Chthoniidae). Entomological News 83: 248-256.

Muchmore, W.B. (1984). Pseudoscorpions from Florida and the Caribbean area. 13. New species of Tyrannochthonius and Paraliochthonius from the Bahamas, with discussion of the genera (Chthoniidae). Florida Entomologist 67: 119-126.

Roth, V.D. and Brown, W.L. (1976). Other intertidal airbreathing arthropods. In Cheng, L. (ed.), Marine insects: 119-150. North-Holland Publishing Co.: Amsterdam and Oxford.

Schulte, G. (1976). Litoralzonierung von Pseudoskorpionen an der nordamerikanischen Pazifikküste (Arachnida: Pseudoscorpiones: Neobisiidae, Garypidae). Entomologica Germanica 3: 119 124.

Vachon, M. (1960). Sur une nouvelle espèce halophile de Pseudoscorpions de l'Archipel de Madère: Paraliochthonius hoestlandti (Fam. des Chthoniidae). Bulletin du Muséum National d'Histoire Naturelle, Paris (2) 32: 331-337.

Weygoldt, P. (1969). The biology of pseudoscorpions. Harvard University Press: Cambridge, Massachusetts.

Manuscript received 10 July 2006; accepted 30 August 2006 